\title{
Powder Metallurgy Prepared Al Alloys and Their „Self-Healing“ Possibilities
}

\author{
Alena Michalcová, Anna Knaislová, Ivo Marek, Zbyněk Veselka, Jaroslav Vavř́k, Tadeáš Bastl, Tomáš Hrdlička, Daniel \\ Kučera, Luana Luwan Sun, Dalibor Vojtěch \\ Department of Metals and Corrosion Engineering, University of chemistry and technology, Technicka 5, Prague 6, 16628, \\ Czech Republic.E-mail: michalca@vscht.cz, vojtechd@vscht.cz
}

\begin{abstract}
Microstructure and mechanical properties of powder metallurgically prepared AISi24Fe3 alloy are presented in this article. The alloy was prepared in form of rapidly solidified ribbons by melt spinning process. Consequently, the ribbons were crushed into powder in a ball mill and compacted by spark plasma sintering. Grain size of prepared alloy was less than $1 \mu \mathrm{m}$, Vickers hardness HV0.1 reached value 214, yield strength and ultimate compressive strength were 611 and $778 \mathrm{MPa}$, respectively. To obtain material with possible self-healing proprerties, it was necessary to enrich material by fine dispersed $\mathrm{Ag}_{2} \mathrm{Al}$ particles. The AISi24Fe3 powder particles were sputtered by $5 \mathrm{~nm}$ layer of silver before sintering. The total amount of $\mathrm{Ag}$ in bulk sample was approximately 0.1 wt. \%. The microstructure of Ag containing alloy was comparable to the basic one. The Ag nanoparticles were present on several particle boundaries. The influence of $\mathrm{Ag}$ presence on Vickers hardness of the material was not observed, as the values $\mathrm{HVO} .1$ was 212 . After a heat treatment $\left(450{ }^{\circ} \mathrm{C} / 1 \mathrm{~h}\right)$, silver transformed to equilibrial $\mathrm{Ag}_{2} \mathrm{Al}$ phase, present in material in form of nanoparticles no more decorating strictly the particles boundaries.
\end{abstract}

Keywords: Aluminium, microstructure, TEM, sputtering

\section{Acknowledgement}

Authors thank for financial support by Czech Science Foundation, project No. GJ17-25618Y

\section{References}

[1] XU, C.L., WANG, H.Y., QIU, F., YANG, Y.F., JIANG, Q.C. (2006) Cooling rate and microstructure of rapidly solidified Al-20 wt.\% Si alloy. In: Materials Science and Engineering A Vol. 417, pp. 275-280. Elsevier B.V. The Netherlands.

[2] RAJABI, M., VAHIDI, M., SIMCHI, A., DAVAMI, P. (2007). Effect of rapid solidification on the microstructure and mechanical properties of hot-pressed Al-20Si-5Fe alloys. In: Materials Characterization, Vol. 60, pp. 13701381. Elsevier B.V. The Netherlands.

[3] NÁPRSTKOVÁ, N., CAIS, J., INGALDI, M. (2016). Modification of AlSi9CuMnNi Alloy by Antimony and Heat Treatmentand Their Influence on Tool Wear after Turning. In: Manufacturing Technology, Vol. 16, No. 1, pp. 209-214. Faculty of Production Technology and Management. CR.

[4] NÁPRSTKOVÁ, N., ČERVINKA, R., KUSMIERCZAK, S., CAIS, J. (2015). Modifications AlSi9CuMnNi Alloy by Antimony and Heat Treatment and Their Influence on the Resulting Structure. In: Manufacturing Technology, Vol. 15, No. 4, pp. 634-638. Faculty of Production Technology and Management. CR.

[5] MICHALCOVÁ, A., VOJTĚCH, D., KUBATÍK, T.F., NOVÁK, P., DVOŘÁK, P. (2014). Structural Description of Powder Metallurgy Prepared Materials. In: Manufacturing Technology, Vol. 14, No. 3, pp. 359-362. Faculty of Production Technology and Management. CR.

[6] PRŮŠA, F., VOJTĚCH, D., BLÁHOVÁ, M., MICHALCOVÁ, A., KUBATÍK, T.F., ČÍŽEK, J. (2015). Structure and mechanical properties of $\mathrm{Al}-\mathrm{Si}-\mathrm{Fe}$ alloys prepared by short-term mechanical alloying and spark plasma sintering. In: Materials and Design, Vol. 75, pp. 65-75. Elsevier B.V. The Netherlands.

[7] GRABOWSKI B., TASAN C.C. (2016) Self-Healing Metals. In: Hager M., van der Zwaag S., Schubert U. (eds) Self-healing Materials. Advances in Polymer Science, vol 273. Springer, Cham. The Netherlands.

[8] HAUTAKANGAS,S., SCHUT, H., VAN DER ZWAAG, S., RIVERA DiAZ DEL CASTILLO, P. E. J., VAN DIJK, N.H. The role of the aging temperature on the self healing kinetics in an underaged AA2024 aluminium alloy.In: Proceedings of the First International Conference on Self Healing Materials, 18-20 April 2007 Noordwijk aan Zee, Springer 2007., The Netherlands.

[9] MICHALCOVÁ, A., MAREK. I., KNAISLOVÁ, A., LUWAN SUN, L. (2017). Preparation and Characterization of Al-TM alloys with possible self-healing properties. In: 3rd International workshop on TEM spectroscopy Workshop in Material Science, June 19th - 22nd, 2017 at the Ångström Laboratory in Uppsala, Sweden. 